DOI: $10.2478 / \mathrm{v} 10014-011-0005-9$

COBISS Code 1.01

Agrovoc descriptors: monilinia, fungi, pathogens, infection, symptoms, fungal diseases, crop losses,damage, morphology, geographical distribution, hosts, disease transmission, identification

Agris category code: h2

\title{
Monilinia pathogens of cultivated and native Vaccinium species in Slovenia
}

\author{
Alenka MUNDA ${ }^{1)}$
}

Received: April 2, 2011; accepted: May 16, 2011

Delo je prispelo: 2. aprila 2011; sprejeto: 16. maja 2011

\begin{abstract}
The fungal genus Monilinia comprises several aggressive and economically important plant pathogens. The aim of this study was to examine Monilinia species that belong to the Disjunctoriae group and are specifically pathogenic to Vaccinium hosts. 23 samples of Vaccinium hosts showing symptoms of infection with Monilinia $s p$. were collected in the years 2004 - 2009. Monilinia species were isolated and identified using morphological and molecular methods. Three species from the Disjunctoriae group were identified: $M$. baccarum, M. urnula and $M$. vaccinii-corymbosi. Morphology of the encountered species is briefly described. Their distribution and host range are presented and the diseases they cause on their respective hosts are described.
\end{abstract}

Key words: Monilinia baccarum, Monilinia urnula, Monilinia vaccinii-corymbosi, Disjunctoriae, Vaccinium, Slovenia

\section{IZVLEČEK}

\section{PATOGENE GLIVE IZ RODU MONILINIA NA GOJENIH IN SAMONIKLIH VRSTAH RODU Vaccinium V SLOVENIJI}

Rod Monilinia združuje številne agresivne in gospodarsko pomembne patogene glive. Predmet raziskave so bile vrste rodu Monilinia, ki sodijo $\mathrm{v}$ skupino Disjunctoriae in so specializirane na gostitelje iz rodu Vaccinium. V letih 2004 2009 smo zbrali 23 vzorcev rastlin iz rodu Vaccinium, pri katerih smo ugotovili znamenja okužbe s temi glivami. S standardnimi mikroskopsko morfološkimi in molekularnimi tehnikami smo identificirali tri glive iz skupine Disjunctoriae: M. urnula, $M$. baccarum in $M$. vaccinii-corymbosi. V prispevku so opisane glavne morfološke značilnosti ugotovljenih vrst, njihova razširjenost in gostitelji v Sloveniji ter bolezni, ki jih posamezne vrste povzročajo pri svojih specifičnih gostiteljih.

Ključne besede: Monilinia baccarum, Monilinia urnula, Monilinia vaccinii-corymbosi, Disjunctoriae, Vaccinium, Slovenija

\section{INTRODUCTION}

The fungal genus Monilinia Honey (Ascomycota, Leotiomycetes, Helotiales, Sclerotiniaceae) comprises several aggressive and economically important plant pathogens (Batra, 1991). They affect several fruit tress and shrubs and cause blights, cankers and fruit rot. Their hosts mainly belong to the families Rosaceae and Ericaceae.

Altogether 31 Monilinia species have been described. Honey (1936) established two informal sections within the genus Monilinia, the Junctoriae and the
Disjunctoriae. This division was based on morphological characters, life histories and host preferences of included species and was also supported by phylogenetics analyses (Holst-Jensen et al., 1997). All major pathogens of fruit trees and shrubs belong to the Junctoriae group. The best known representatives of this group in Europe are M. laxa and M. fructigena. They are polytrophic and affect a wide range of rosaceous hosts. Another Junctoriae species, $M$. fructicola, is native to North and South America, Australia and New Zealand and has been introduced to

\footnotetext{
${ }^{1}$ Dr., Agricultural Institute of Slovenia, Hacquetova 17, SI-1000 Ljubljana, Slovenia, e-mail: alenka.munda@kis.si
} 
Europe only recently (EPPO, 2002). All three species induce similar symptoms: blossom blight, dieback of twigs, canker formation and fruit rot known as Monilinia brown rot. They consequently cause conspicuous economic loss in fruit growing regions worldwide.

The vast majority of Monilinia species belong to the Disjunctoriae group; 27 species are currently included in this section (Batra, 1991). They have a common morphological characteristic, the disjunctors i.e. spindle like appendages intercalated between conidia in the conidial chain. This characteristic is reflected in the name of the group. Disjunctoriae species inhabit a variety of wild and cultivated Rosaceae and Ericaceae. Host specialization is more pronounced in the Disjunctoriae group than in the Junctoriae group. While some species specifically infect Rosaceae from genera Sorbus, Crategus, Amelanchier and Prunus, the majority of Disjunctoriae species specialize to Ericaceae. They affect different genera, those with fleshy fruits (Vaccinium, Gaylussacia, Oxycoccus) and those with capsular fruits (Rhododendron, Azalea, Ledum). They cause blight of flower clusters, dieback of shoots and mummification of fruits of their respective hosts. Only two species from this group cause economically significant damage, $M$. vacciniicorymbosi and $M$. oxycocci, the causative agents of the mummy berry disease and the cotton boll disease of blueberries and cranberries, respectively (Batra, 1983).

Monilinia species from the Disjunctoriae group have a complex life cycle and regularly form a sexual and an asexual reproductive stage (Batra, 1983). They produce two types of spores that have different dispersal mechanisms and infect specific host tissues. Each spore type is produced only once in a growing season and has very limited opportunity to cause infection. In spring, apothecia develop on overwintered mummified fruits (termed pseudosclerotia) and release ascospores that initiate primary infection of newly emerging tissues. Asexual spores (macroconidia) are produced on blighted plant parts and subsequently spread infection to flowers. In contrast, the Junctoriae species rely mainly on asexual reproduction and produce several crops of macroconidia that spread infection to flowers and fruits.

The aim of this study was to examine the occurrence, ecology and diseases caused by Monilinia species from the Disjunctoriae group in Slovenia. Species that are specifically pathogenic to Vaccinium hosts were of our primary interest.

\section{MATERIALS AND METHODS}

\subsection{Field sampling}

In the years $2004-2009$ we collected 23 samples of ericaceous hosts showing symptoms of infection with Monilinia $s p$. Several samples were collected from high-bush blueberry (Vaccinium corymbosum) growing in the plantations situated in the Ljubljana Wetland. Other samples were collected from native Vaccinium species growing in forests situated in the lowland and mountainous regions of Gorenjska and Štajerska (Table1).

Monilinia species were isolated from blighted twigs, leaves and mummified fruits as well as from mature apothecia. Isolation was performed by culturing pieces of necrotic host tissue on potato dextrose agar (PDA) or by spreading ascospore suspension on PDA plates and isolating individual germinating ascospores. The PDA medium was amended with a mixture of streptomycin sulphate and penicillin to prevent bacterial contamination during the isolation. Isolates were kept on PDA slants at $4{ }^{0} \mathrm{C}$ for long term storage. Apothecia and pseudosclerotia were dried and saved as herbarium specimens.

\subsection{Identification of isolates}

Monilinia isolates were identified by colony characteristics, morphology of macroconidia, microconidia and disjunctors as well as by characteristics of pseudosclerotia and apothecia.
Morphological characteristics were studied by using standard microscopic techniques. Free hand sections of apothecia and pseudosclerotia were used for morphological studies. Observations and measurements were done in lactophenol with cotton blue. 25 to 50 asci, ascospores, conidia and disjunctors were measured. Cultural characteristics were observed after growing ten replicates of isolates for three weeks in the dark at 20 and $25{ }^{\circ} \mathrm{C}$ on PDA and YEMEA (malt agar with yeast extract).

Morphological identification of isolates was confirmed by molecular tools. DNA was extracted from pure cultures using the DNeasy Plant Mini Kit (Qiagene, Germany). Amplification of the ITS rDNA region, comprised of the 3' end of the $18 \mathrm{~S}$ rRNA gene, the internal transcribed spacer (ITS) 1, the 5.8S rRNA gene, ITS2, and the 5' end of the $26 \mathrm{~S}$ rRNA gene, was performed with the primer pair ITS1 and ITS4 (White et al., 1990). The PCR cycling parameters were: one cycle of $94{ }^{\circ} \mathrm{C}$ for $3 \mathrm{~min} ; 35$ cycles of $94{ }^{0} \mathrm{C}$ for $40 \mathrm{sec}, 54$ ${ }^{0} \mathrm{C}$ for $50 \mathrm{sec}, 72{ }^{0} \mathrm{C}$ for $2 \mathrm{~min}$; and a final cycle of $72{ }^{0} \mathrm{C}$ for 10 min. The PCR products were cleaned using Jetquick (Genomed, Germany). Sequencing was done at a sequencing facility (Macrogen, Korea) using the same primers as for the PCR reactions. Sequence data were analyzed using BioEdit Alignment Editor. Sequences were analyzed against the GenBank "nr/nt" database using BLASTN. 
Table 1: Isolates of Monilinia species examined in the study

\begin{tabular}{|c|c|c|c|c|}
\hline Isolate code $*$ & Species of Monilinia & Locality & Host & Source of isolates \\
\hline M311 & M. vaccinii-corymbosi & Drenov Grič, UTM 33TVL59 & V. corymbosum & conidia \\
\hline M422 & M. vaccinii-corymbosi & Valburga, UTM 33TVM51 & V. corymbosum & blighted twig \\
\hline M423 & M. vaccinii-corymbosi & Valburga, UTM 33TVM51 & V. corymbosum & conidia \\
\hline M424, CBS 120174** & M. vaccinii-corymbosi & Borovnica, UTM 33TVL58 & V. corymbosum & conidia \\
\hline M425 & M. vaccinii-corymbosi & Borovnica, UTM 33TVL58 & V. corymbosum & blighted twig \\
\hline M426 & M. vaccinii-corymbosi & Smrekovec, UTM 33TVM94 & V. corymbosum & conidia \\
\hline M427 & M. vaccinii-corymbosi & Drenov Grič, UTM 33TVL59 & V. corymbosum & blighted blossoms \\
\hline M430 & M. vaccinii-corymbosi & Borovnica, UTM 33TVL58 & V. corymbosum & apothecium \\
\hline M060824.1 & M. urnula & Pohorje, Pesek , UTM 33TWM24 & V. vitis-idaea & mummified fruit \\
\hline M060824.2 & M. urnula & Pohorje, Rogla, UTM 33TWM24 & V. vitis-idaea & mummified fruit \\
\hline M060824.3 & M. urnula & Ribnica na Pohorju, UTM 33TWM25 & V. vitis-idaea & mummified fruit \\
\hline M060824.4 & M. urnula & Pohorje, Lovrenško barje, UTM 33TWM24 & V. vitis-idaea & mummified fruit \\
\hline M060824.5 & M. urnula & Pohorje, Osankarica, UTM 33TWM34 & V. vitis-idaea & mummified fruit \\
\hline M419 & M. urnula & Sp. Palovče nad Kamnikom, UTM 33TVM71 & V. vitis-idaea & mummified fruit \\
\hline M420 & M. urnula & Pokljuka, Šijec, UTM 33TVM23 & V. vitis-idaea & mummified fruit \\
\hline M421/K & M. urnula & Pokljuka, Šijec, UTM 33TVM23 & V. vitis-idaea & conidia \\
\hline M060824.7 & M. baccarum & Pohorje, Pesek , UTM 33TWM24 & V. myrtillus & mummified fruit \\
\hline M060824.8 & M. baccarum & Pohorje, Klopni vrh, UTM 33TWM34 & V. myrtillus & mummified fruit \\
\hline M060824.9 & M. baccarum & Pohorje, Lovrenško barje, UTM 33TWM24 & V. myrtillus & mummified fruit \\
\hline M313 & M. baccarum & Pokljuka, pod pl. Lipanco, UTM 33TVM13 & V. myrtillus & mummified fruit \\
\hline M429 & M. baccarum & Sp. Palovče nad Kamnikom, UTM 33TVM71 & V. myrtillus & mummified fruit \\
\hline M431 & M. baccarum & Krvavica nad Taborom, UTM 33TVM91 & V. myrtillus & mummified fruit \\
\hline M432 & M. baccarum & Pokljuka, Mrzli Studenec, UTM 33TVM23 & V. myrtillus & apothecium \\
\hline
\end{tabular}

* all isolates are kept in the culture collection at the Agricultural Institute of Slovenia

** isolate was deposited at Centraalbureau voor Schimmelcultures (CBS), Utrecht, the Netherlands

\section{RESULTS AND DISCUSSION}

Three species of the genus Monilinia were detected on ericaceous hosts with fleshy berries: M. baccarum, $M$. urnula and M. vaccinii-corymbosi. Brief morphological description and notes on the ecology of each species are given below. Only representatives of the genus Vaccinium were found to be infected with Monilinia species. No signs of infection were observed on Oxycoccus and Arctostaphylos species although they were regularly examined for the occurrence of twig blight, mummified fruits and apothecia.

3.1 Monilinia urnula (Weinmann) Whetzel

Anamorph: Monilia urnula Batra

Morphology of the fungus

Pseudosclerotia were reddish brown, hollow, open above and below. They retained the shape of a mature fruit and incorporated some remains of host tissue 
(mesocarp, ovules, aborted seed). In cross section an outer and inner rind and a thick medulla were clearly visible. Mature pseudosclerotia were collected in late August and September.

Apothecia occurred in late spring (from the end of May until the beginning of June, depending on locality and weather conditions). Apothecia were rare and difficult to find. They arose from fallen mummified fruits (pseudosclerotia) that overwintered in moist patches. We often found them among Sphagnum moss. Usually only one apothecium developed per pseudosclerotium. Apothecia were nut brown, cupulate when young, later discoid with slightly everted margin, disc $5-8 \mathrm{~mm}$ in diameter. Stipe of apothecia was up to $50 \mathrm{~mm}$ long, dark brown. Fascicles of thick walled hyphae, the so-called rhizoidal tufts, were clearly visible at the base of stipes. Hymenium was light brown, asci cylindrical, eight spored and measured $152.8-166.3 \mu \mathrm{m}$ (mean162.1 $\mu \mathrm{m}$ ) x $9.7-10.9 \mu \mathrm{m}$ (mean $10.3 \mu \mathrm{m}$ ). Ascospores were hyaline, ellipsoid and measured 11.4 - $15 \mu \mathrm{m}$ (mean 13 $\mu \mathrm{m})$ x $5-6.5 \mu \mathrm{m}$ (mean $5.8 \mu \mathrm{m}$ ). Paraphyses were filiform and septate at the base.

Macroconidia of the anamorphic state Monilia urnula were observed in early summer (from June until the beginning of July). They appeared as white covering on the convex side of young shoots and on the under surface of leaves, particularly along midribs. Macroconidia were limoniform, hyaline and measured 25.6 - $41.4 \mu \mathrm{m}$ (mean $31.13 \mu \mathrm{m})$ x 15.5 - $27.5 \mu \mathrm{m}$ (mean $20.7 \mu \mathrm{m}$ ). Mature macroconidia were separated by spindle like structures - disjunctors. The disjunctors are involved in the dissemination of macroconidia. They were first described by Woronin (1888) in M. urnula and later found to be present in all species belonging to the Disjunctoriae group. The disjunctors of M. urnula are conspicuous and robust. They measure $4.4 \times 2 \mu \mathrm{m}$ when intercalated between macroconidia and 9.4 × $2 \mu \mathrm{m}$ when detached.

The colonies on PDA and YEMEA were slow growing; at $25^{\circ} \mathrm{C}$ they overgrew a $90 \mathrm{~mm}$ petri dish in 21 days. The mycelium was white and beige on reverse, loose but compact in places. Black stroma, buried deep in agar, was observed in aging colonies. Macroconidia did not develop, but microconidia were abundant, particularly in mature colonies growing in darkness. They were globose, hyaline, 2 - $3 \mu \mathrm{m}$ wide. Microconidia are characteristic for many Monilinia species. They form on macroconidia, ascospores and vegetative hyphae either directly or on flask shaped phialides (Batra, 1991).

Habitat, distribution and diseases caused

M. urnula is a monotrophic species that inhabits only Vaccinium vitis-idaea. There are several records of this species in Europe, mainly from Scandinavia, Austria and United Kingdom (Gjaerum, 1969; Woronin, 1888; Dennis, 1968). It was reported also from Japan (Kobayashi, 2007).

M. urnula infections result in the blight of young shoots and leaves and the development of brown, hard berries (mummy berries). Infection of shoots and leaves in early summer is performed by ascospores while mummification of berries results from conidial infection of flowers.

M. urnula was thoroughly studied by the Russian mycologist Woronin (1888) in his monographic study of Sclerotiniaceae on Vaccinium species with fleshy berries. He investigated the life cycle of the fungus and established the anamorph / teleomorph relationship. Woronin (1888) described entry of conidia through the stigma, growth along the stylar canal and development of white cottony mass of mycelium around ovules and placenta. The infected berries appear normal until the fungus invades the mesocarp and forms pseudosclerotium. Then they turn brown and fall to the ground.

\subsection{Monilinia baccarum (Schröter) Whetzel Anamorph: Monilia baccarum Migula}

Morphology of the fungus

Pseudosclerotia were light grey, sometimes grayish pink and could be found in the litter below host plants. Mature pseudosclerotia were hollow and open at the distal end. Remains of seeds and ovules were present in the young ones. An outer and an inner rind were visible on cross section. Mature pseudosclerotia were collected from July to September.

In spring, one or two apothecia developed from the overwintered pseudosclerotia. Apothecia developed by the end of May at higher elevations in the mountainous region. They probably occur earlier in the lowland. They were dark brown, cupulate with upward margins and measured $6 \mathrm{~mm}$ in diameter. Stipe was dark brown, 40 - $50 \mathrm{~mm}$ long, not ornamented with rhizoidal tufts. Hymenium was brown, asci cylindrical, eight spored and measured 140 - $180 \mu \mathrm{m}$ (mean $170 \mu \mathrm{m})$ x $10-14$ $\mu \mathrm{m}$ (mean $13 \mu \mathrm{m})$. Ascospores were hyaline, ellipsoid and measured $14.5-20.8 \mu \mathrm{m}$ (mean $17.3 \mu \mathrm{m}$ ) x $5.9-$ $7.3 \mu \mathrm{m}$ (mean $6.6 \mu \mathrm{m}$ ). Paraphyses were filiform, septate at the base and unbranched.

Macroconidia of the anamorphic state Monilia baccarum were observed from late spring to early summer, depending on the locality. They appeared as grayish white mantle on the concave side of new shoots and leaves. Macroconidia were limoniform, hyaline and 
measured $19-28 \mu \mathrm{m}$ (mean $23.5 \mu \mathrm{m}) \times 14-21 \mu \mathrm{m}$ (mean $17 \mu \mathrm{m}$ ). They were separated by $3-4 \mu \mathrm{m}$ long disjunctors.

The colonies on PDA and YEMEA were slow growing and reached the diameter of $50 \mathrm{~mm}$ in 21 days. The mycelium was white, grayish brown on reverse, compact. Black superficial stroma developed in older colonies. Macroconidia were not observed in culture. Microconidia were present on hyphae, they were globose, hyaline, 2 - $3 \mu \mathrm{m}$ wide.

\section{Habitat, distribution and diseases caused}

$M$. baccarum is a monotrophic species restricted to Vaccinium myrtillus. It is known from Scandinavia, Austria, Belgium, Germany and United Kingdom (Batra, 1991; Gjaerum, 1969; Rehm, 1885; Woronin, 1888; Dennis, 1968; Palmer, 1988).

M. baccarum causes blight of newly emerging shoots; they turn brown and droop. The infected bilberries turn pale, dry, shrivel, mummify and fall to the ground. They are called white berries due to the fine whitish layer of host cells (including epidermis) that cover the berry (Batra, 1991).

\subsection{Monilinia vaccinii-corymbosi (Reade) Honey Anamorph: Monilia vaccinii-corymbosi Reade}

\section{Morphology of the fungus}

Pseudosclerotia were dark brown, robust, hollow, distinctively ribbed, flattened and opened at both poles. In cross section an outer and an inner black rind were visible. Mature pseudosclerotia fell to the ground. They were found in masses under infected host plants by the end of summer. They persisted until next spring.

At the end of March until the end of April three to four apothecia developed from the overwintered pseudosclerotia. Apothecia were reddish brown to umber, cupulate with recurved margin when young, later discoid with slightly crenate margin, disc $10-12$ $\mathrm{mm}$ in diameter. Stipe was dark brown, $40-50 \mathrm{~mm}$ long, rhizoidal tufts were not observed. Hymenium was brown, asci cylindrical, eight spored and measured 177 $230 \mu \mathrm{m}$ (mean $181.6 \mu \mathrm{m})$ x $8-14.7 \mu \mathrm{m}$ (mean 11.2 $\mu \mathrm{m})$. Ascospores were hyaline, ellipsoid and measured 15 - $19.2 \mu \mathrm{m}$ (mean $16.7 \mu \mathrm{m}$ ) x 8 - $10.7 \mu \mathrm{m}$ (mean 9.6 $\mu \mathrm{m})$. Paraphyses were filiform and unbranched.

Macroconidia of the anamorphic state Monilia vacciniicorymbosi were observed in spring (early May), just before the onset of flowering. They appeared as dense grayish covering on the convex side of bent current year twigs, on petioles and along midribs of blighted leaves. Macroconidia were limoniform, hyaline and measured
$21.9-30.1 \mu \mathrm{m}$ (mean $25.7 \mu \mathrm{m})$ x $11.7-15.3 \mu \mathrm{m}$ (mean $13.8 \mu \mathrm{m})$. They were borne in long, branched moniloid chains. Individual macroconidia were intercalated with $3-5 \mu \mathrm{m}$ long, fusiform disjunctors.

The colonies on YEMEA were slow growing and reached $7-8 \mathrm{~cm}$ in diameter after 21 days at $20^{\circ} \mathrm{C}$ in the dark. The mycelium was white to beige and compact. Brown stroma developed in older cultures. The reverse of plates was brown, with yellow or honey pigmentation in some cultures. Hyphae were broad and often assembled in fascicles. Production of macroconidia was scarce. Microconidia were abundant on hyphae, on germinating ascospores and macroconidia. They were hyaline, globose, 3 - 4 ųm in diameter.

\section{Habitat, distribution and diseases caused}

M. vaccinii-corymbosi is endemic to North America. It is oligotrophic there and affects several species of the genus Vaccinium (Batra, 1983). In our study we found it on Vaccinium corymbosum only.

M. vaccinii-corymbosi is a major problem of commercial and wild blueberries throughout North America. It causes the mummy berry disease of highbush blueberry (V. corymbosum), low-bush blueberry (V. angustifolium), rabbiteye blueberry (V. ashei) and several other North American Vaccinium species (Batra, 1991). The pathogen induces two kinds of damage: wilting and browning of young shoots, leaves and flower clusters in early spring and mummification of maturing fruits in summer. Blighting of flower clusters and mummification of fruits significantly reduce the current year yield while blighting of shoots can have a long term effect on blueberry production in the following years. Blighting is caused by ascospore infection of buds in early spring. The development and release of ascospores are well correlated with the bud brake of host plants (Batra 1983; Lehman and Oudemans 2000). Macroconidia later develop on blighted plant parts. Insect pollinators and wind transfer them to stigmas of open flowers where they germinate, subsequently enter the fruit locules and finally invade the fruit mesocarp (Batra and Batra, 1985; Ngugi et al., 2002). Young fruits show no signs of infection and do not differ from healthy ones until maturity. Then they become wrinkled, light pink to brown, hard and drop to the orchard ground.

M. vaccinii-corymbosi was first documented in Europe in 2003 in Austria (Gosch 2003). A year later (in summer 2004) high-bush blueberry growers in Slovenia also found the first mummified fruits in their plantations. Already in spring 2005 severe infection of new shoots and flowers occurred. The extent of damage reached up to $50 \%$ in certain high-bush blueberry varieties. 


\section{CONCLUSIONS}

The primary goal of our work was to study Monilinia species that inhabit Vaccinium hosts and belong to the Disjunctoriae group. Species from the Disjunctoriae group have been much less thoroughly studied than those from the Junctoriae group. There are several reasons for this. Most Disjunctoriae species are rare or restricted in their distribution. Their fruit bodies are small and difficult to find in the field. Besides, they mostly cause economically less significant damage comparing to the Junctoriae and therefore receive less attention from phytopathologists.

Three Disjunctoriae species were encountered in Slovenia: $M$. baccarum, $M$. urnula and $M$. vacciniicorymbosi. $M$. baccarum and $M$. urnula were pathogenic to $V$. myrtillus and $V$. vitis-idaea, respectively. These two hosts are sympatric in our region and frequently inhabit the same site. However, each host was strictly colonized only by its respective Monilinia pathogen and no cross infections were observed. In contrast to the monotrophic species $M$. urnula and $M$. baccarum, M. vaccinii-corymbosi exhibits a polytrophic character and infects several North American blueberry species. It is listed among pathogens that have the greatest economical impact on blueberry production in North America. It was presumably introduced to our country with the infected planting material of high-bush blueberry. It remained restricted to this North American host. In the last years it became well established and widespread in our highbush blueberry plantations where it significantly affects the production of high-bush blueberries.

\section{ACKNOWLEDGEMENTS}

I wish to thank Mrs. Aleksandra Podboj Ronta for her skilful assistance in field and laboratory work.

\section{REFERENCES}

Batra, L.R. 1983. Monilinia vaccinii-corymbosi (Sclerotiniaceae): its biology on blueberry and comparison with related species. Mycologia 75: 131-152.

Batra, L.R. 1991. World species of Monilinia (Fungi): their ecology, biosystematics and control. Mycologia Memoir 16. Berlin, J. Cramer: 246 p

Batra, L.R., Batra, S.W.T. 1985. Floral mimicry induced by mummy berry fungus exploits host's pollinators as vectors. Science 228: 1011-1013.

Dennis, R. W.G. 1968. British Ascomycetes. Lehre, Cramer: $445 \mathrm{p}$.

EPPO, 2002. First report of Monilinia fructicola in France. EPPO Reporting Service 1, 2002/003.

Gjaerum, H.B. 1969. Some fruit inhabiting Sclerotinias in Norway. Friesia 9: 18-28.

Gosch, C. 2003. Monilinia vaccinii-corymbosi on high-bush blueberries (Vaccinium corymbosum L.): also in Europe. Europ. J. Hort. Sci. 68: 238-241.

Holst-Jensen, A., Kohn, L.M., Jakobsen, K.S., Schumacher, T. 1997. Molecular phylogeny and evolution of Monilinia (Sclerotiniaceae) based on coding and noncoding rDNA sequences. American Journal of Botany 84: 686-701.

Honey, E.E. 1936. North American species of Monilnia I. Occurrence, grouping, and life-histories. Amer.J. Bot. 23: $100-106$.
Kobayashi T. 2007. Index of fungi inhabiting woody plants in Japan. Host, Distribution and Literature. Kyoiku, Kyokai Publishing Co.: 1227 p.

Lehman, J. S., Oudemans, P. V. 2000. Variation and heritability of phenology in the fungus Monilinia vacciniicorymbosi on blueberry. Phytopathology 90 (4): 390395.

Ngugi, H.K, Scherm, H., Lehman, J.S. 2002. Relationships between blueberry flower age, pollination, and conidial infection by Monilinia vaccinii-corymbosi. Phytopathology 92: 1104-1109.

Palmer, J. T. 1988. Investigations into the Sclerotiniaceae. Lejunia 127: 1- 40 .

Rehm, H. 1885. Ascomyceten: Sclerotinia baccarum. Fasc. XVI. Hedwigia 24: 7-17.

White, T.J., Bruns, T.D., Lee, S., Taylor, J.W. 1990. Amplification and direct sequencing of fungal ribosomal RNA genes for phylogenetics. In: PCR protocols: a guide to methods and applications. San Diego, Academic Press: 315-322.

Woronin, M. 1888. Über die Sclerotienkrankheit der Vaccinieen-beeren. Mem. Acad. Imp. Sci. St. Petersbourg VII 36 (6): 1-49. 